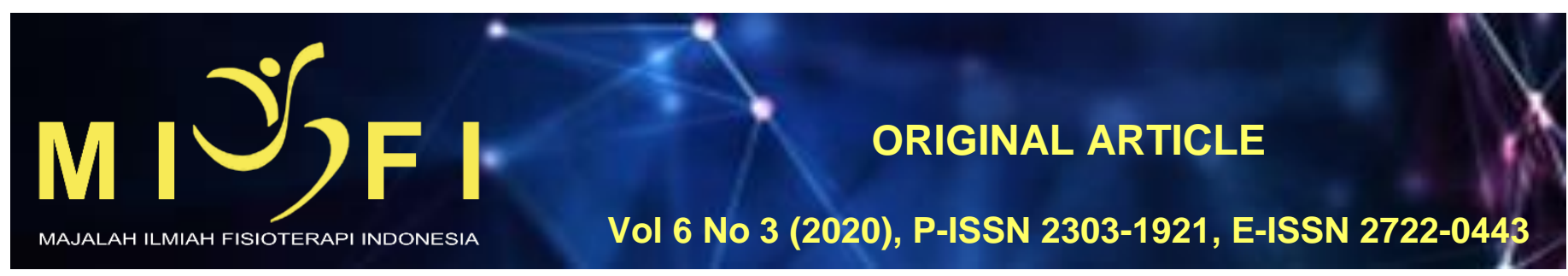

\title{
HUBUNGAN KEJADIAN KNEE OSTEOARTRHITIS TERHADAP KELUHAN LOW BACK PAIN MIOGENIK PADA MASYARAKAT PASAR KRENENG KOTA DENPASAR
}

\section{Gusti Ayu Alit Triwahyuni ${ }^{1}$, Ni Wayan Tianing ${ }^{2}$, Anak Ayu Nyoman Trisna Narta Dewi ${ }^{3}$, Made Widnyana ${ }^{3}$}

${ }_{1}^{1}$ Program Studi Sarjana Fisioterapi dan Profesi Fisioterapi, Fakultas Kedokteran, Universitas Udayana, Denpasar, Bali

2Departemen Biokimia, Fakultas Kedokteran, Universitas Udayana,Denpasar,Bali

${ }^{3}$ Departemen Fisioterapi, Fakultas Kedokteran, Universitas Udayana, Denpasar, Bali

\section{triwahyunialit@gmail.com}

\begin{abstract}
ABSTRAK
Osteoarthritis menyerang persendian yang mempunyai titik tumpu besar salah satunya knee joint. Kondisi knee osteoarthritis ini dapat menimbulkan keluhan pada area lain salah satunya low back pain. Low back pain yang terjadi pada penderita knee osteoarthritis merupakan low back pain non spesifik tipe miogenik yang terjadi karena indirect muscle function. Tujuan penelitian ini adalah untuk mengetahui hubungan antara kejadian knee osteoarthritis dengan keluhan low back pain miogenik pada masyarakat Pasar Kreneng Kota Denpasar. Penelitian ini menggunakan rancangan studi observasional analitik secara cross sectional dengan teknik pengambilan peserta penelitian secara simple random sampling. Peserta penelitian berjumlah 52 orang yaitu 42 orang perempuan dan 10 orang lakilaki.Pengumpulan data dilakukan dengan pemeriksaan knee osteoarthritis yang dilakukan oleh fisioterapis dan .pemeriksaan low back pain miogenik menggunakan kuisioner Rolland Morris Low Back Pain and Disability serta palpasi. Hasil rerata usia dan IMT pada penelitian yakni 52,5 tahun dan $28,1 \mathrm{~kg} / \mathrm{m}^{2}$. Pada perhitungan analisis data dengan uji chi-square diperoleh nilai $(p=0,781)$ dimana $(p>0,05)$ yang berarti tidak ada hubungan antara kejadian $k n e e$ osteoarthritis dengan keluhan low back pain miogenik pada masyarakat Pasar Kreneng Kota Denpasar. Nilai $p$ yang tidak signifikan ini dipengaruhi oleh faktor alat ukur, peserta penelitian yang tidak representatif, motivasi, persepsi nyeri, dan aktivitas fisik peserta penelitian. Berdasarkan hasil penelitian tersebut maka dapat disimpulkan bahwa tidak terdapat hubungan antara kejadian knee osteoarthritis dengan keluhan low back pain miogenik pada masyarakat Pasar Kreneng Kota Denpasar.
\end{abstract}

Kata kunci: knee osteoarthritis, low back pain miogenik, masyarakat

\section{THE RELATIONSHIP BETWEEN INCIDENCE OF KNEE OSTEOARTRHITIS TO MYOGENIC LOW BACK PAIN IN COMMUNITY OF KRENENG MARKET AT DENPASAR CITY}

\section{ABSTRACT}

Osteoarthritis usually affects the joints that have a large burden point one of the knee joint. This knee osteoarthritis condition can cause complaints in other areas such as low back pain. Low back pain that occurs in knee osteoarthritis patients is a non-specific myogenic low back pain that occurs due to indirect muscle function. The purpose of this research is to know the relationship between knee osteoarthritis with myogenic low back pain on the community of Kreneng market in Denpasar. This study designed by analytic observational in a cross sectional with participant randomized by simple random sampling. The participants of this study amounted to 52 people, 42 women and 10 men. Data collected with knee osteoarthritis examination by physiotherapist and myogenic low back pain test using Rolland Morris Low Back Pain and Disability questionnaire and palpation. The average age and BMI in the study was 52.5 years and $28.1 \mathrm{~kg} / \mathrm{m}^{2}$. In the data analysis with the Chi-square test obtained value $(p=0.781)$ where $(p>0.05)$ which means there is no relationship between the incident knee osteoarthritis with myogenic low back pain in the Community of Kreneng market in Denpasar. This nonsignificant $p$ value is influenced by some factor such as measuring instruments, unrepresentative participants of the study, motivation, pain perception, and the physical activity of research participants. Based on the results of this study, it can be concluded that there is no relationship between the incidents of knee osteoarthritis with myogenic low back pain in community of kreneng market at Denpasar City.

Keywords: knee osteoarthritis, myogenic low back pain, community

\section{PENDAHULUAN}

Tingginya penderita artritis di Bali, membuat penyakit ini berada diperingkat ketiga dalam pola 10 besar penyakit pada pasien di puskesmas di Bali dengan jumlah 115.157 kasus. ${ }^{1}$ Salah satu jenis artritis yang paling banyak dijumpai adalah osteoarthritis dan lebih dikenal sebagai artritis degeneratif. ${ }^{2}$

Osteoarthritis merupakan kondisi dimana terjadi inflamasi pada sendi dan tulang serta jaringan sekitarnya karena tekanan atau pembebanan yang berulang dan konstan. ${ }^{3}$ Osteoarthritis biasanya menyerang persendian besar yang mempunyai titik tumpu besar, seperti hip joint, knee joint, dan ankle joint. ${ }^{4}$

Hasil penelitian terdahulu menemukan kejadian osteoarthritis yang paling banyak terjadi di Swedia merupakan knee joint osteoarthritis dengan angka kejadian sebesar 25,4\% yang terdiagnosa melalui radiografi. ${ }^{4}$ Osteoarthritis merupakan inflamatory disease dan wanita cenderung memiliki respon inflamasi dan kekebalan yang lebih bagus 
dibandingkan laki-laki. Prevalensi knee osteoarthritis pada usia senior lebih besar pada wanita daripada pria hal ini mungkin disebabkan oleh perkembangan dan persistensi sitokin inflamasi pada lutut. Efek ini merupakan efek sekunder akibat pengaruh hormon. Berkurangnya hormon estrogen saat pascamenopause berhubungan dengan peningkatan produksi inflammatory cytokines, seperti interleukin-6 (IL-6). ${ }^{5}$

Adapun faktor risiko lainnya selain usia dan jenis kelamin ialah tingkat pendidikan, riwayat merokok, osteoporosis dan hipertensi. ${ }^{6}$ Penelitian lainnya menjelaskan bahwa osteoarthritis dipengaruhi oleh indeks massa tubuh. Kejadian osteoarthritis lebih banyak pada orang dengan indeks massa tubuh diatas $24,9 \mathrm{~kg} / \mathrm{m}^{2} .7$

Dampak dari osteoarthritis pada knee joint tidak terlihat secara langsung namun dapat terasa dan mengganggu aktivitas keseharian apabila dibiarkan begitu saja. Apabila hal ini dibiarkan secara terus-menerus maka akan terjadi kelainan pada sendi tersebut, seperti knee varus maupun knee valgus ${ }^{8}$ dan yang lebih parah adalah disabilitas pada anggota gerak bawah. Mekanisme terjadinya knee osteoarthritis dimulai dari pembebanan yang besar pada sendi secara terus menerus dan diiringi dengan pengurangan cairan sinovial pada sendi. Akibatnya permukaan sendi akan terkikis seiring dengan pembebanan yang diberikan. ${ }^{9}$ Dari hal tersebut timbulah rasa nyeri dan terganggunya akitivitas keseharian.

Pada kondisi knee osteoarthritis, penderita biasanya mengalami kelemahan pada otot ekstensor dan memendeknya otot fleksor. ${ }^{10}$ Kelemahan pada otot ekstensor merupakan proses kompensasi akibat respon dari persepsi tubuh untuk mengurangi rasa nyeri yang timbul akibat tekanan saat ekstensi penuh Proses kompensasi ini biasanya disebut arthrogenic muscle inhibition (AMI). AMI juga dapat berakibat makin buruk yaitu menyebabkan atrofi pada otot ekstensor salah satunya otot quadriceps. ${ }^{11}$

Low back pain atau nyeri punggung bawah merupakan proses inflamasi pada jaringan di sekitar punggung bawah karena teregang, tertarik ataupun putus. ${ }^{12}$ Low back pain yang terjadi pada penderita knee osteoarthritis merupakan low back pain non spesifik tipe miogenik yang terjadi karena indirect muscle function. Terjadinya keluhan LBP ini diduga disebabkan oleh knee spine syndrome yang merupakan kondisi yang menyebabkan berkurangnya sudut lordosis lumbal yang diakibatkan oleh fase degeneratif knee osteoarthritis.

Berdasarkan kasus gangguan persendian di Bali, kelompok usia 55-74 tahun umumnya mengeluhkan gangguan persendian di sendi lutut kemudian pergelangan kaki. Berdasarkan data tahun 2001-2003 di poliklinik Reumatologi RSUP Sanglah Kota Denpasar, kasus tertinggi merupakan osteoarthritis sebesar 37\% dengan knee joint sebagai kelainan terbanyak dari osteoarthritis diikuti hip joint dan spine. ${ }^{13}$ Pasar merupakan salah satu tempat dengan aktivitas fisik yang beragam. ${ }^{14}$ Diketahui dari penelitian ini, aktivitas fisik berat mempunyai hubungan yang signifikan terhadap kejadian knee osteoarthritis. Salah satu pasar yang terdapat di Kota Denpasar yaitu Pasar Kreneng. Sebanyak $57,4 \%$ penderita knee osteoarthritis mengalami LBP seiring peningkatan WOMAC (Western Ontario and McMaster Universities Osteoarhtritis Index) knee pain score $(\mathrm{p}<0,0001)$. Terjadinya keluhan LBP ini dapat disebabkan oleh knee spine syndrome yang merupakan kondisi berkurangnya sudut lordosis lumbal. ${ }^{15}$ Penelitian terdahulu ini memilki kekurangan salah satunya tidak menjabarkan tipe keluhan low back pain yang ditemukan pada peserta penelitian penelitiannya.

Pada penelitian ini dilakukan pemeriksaan tambahan yaitu palpasi pada bagian punggung bawah untuk menemukan low back pain tipe miogenik. Berdasarkan uraian diatas, penelitian ini dilakukan untuk mengetahui hubungan antara kejadian knee osteoarthritis dengan keluhan low back pain miogenik pada masyarakat Pasar Kreneng Kota Denpasar.

\section{METODE}

Penelitian ini merupakan penelitian observasional analitik yang mengunakan desain cross sectional. Penelitian ini telah lulus uji kelaikan etik dari Komisi Etik Penelitian (KEP) Fakultas Kedokeran Universitas Udayana/ Rumah SAKIT Umum Pusat Sanglah Denpasar dengan nomor 2020.01.1.0004. Adapun kriteria inklusi yakni 1) berusia $\geq 40$ sampai 75 tahun dan 2) memilki IMT $\geq 24,9 \mathrm{~kg} / \mathrm{m}^{2}$. Penelitian ni dilakukan di Pasar Kreneng Kota Denpasar pada bulan MeiJuli 2020. Peserta penelitian pada penelitian ini adalah masyarakat Pasar Kreneng Kota Denpasar yakni pedagang, pembeli, buruh pasar, dan tukang parkir. Peserta penelitian penelitian berjumlah 52 orang yang diambil dengan teknik simple random sampling dengan menggunakan aplikasi Random Generator. Proses randomisasi menggunakan aplikasi ini diawali dengan menyiapkan daftar peserta penelitian dalam bentuk tabel bernomor kemudian dilakukan peneliti menginput jumlah total peserta penelitian dan dilanjutkan dengan mengisi jumlah peserta yang diperlukan untuk penelitian. Hasil randomisasi dari aplikasi ini berupa deretan angka yang sudah diacak dan peneliti memilih urutan peserta sesuai dengan angka hasil randomisasi.

Variabel bebas pada penelitian ini adalah low back pain miogenik sedangkan yang menjadi variabel terikat adalah kejadian knee osteoarthritis. Prosedur pelaksaan penelitian ini diawali dengan mencari calon peserta penelitian di Pasar Kreneng Kota Denpasar kemudian menanyakan kebersediaannya menjadi peserta penelitian. Peneliti kemudian menjelaskan tujuan, manfaat, serta prosedur pelaksanaan penelitian kepada peserta penelitian. Pemeriksaan knee osteoarthritis dan low back pain dilakukan pada semua peserta penelitian. Penelitian ini tidak menggunakan hasil pemeriksaan radiografi untuk mendiagnosis knee osteoarthritis. Pemeriksaan knee osteoarthiritis pada penelitian ini dilakukan oleh fisioterapis mengacu pada 2016 ACR (American College of Rheumatology) revised criteria untuk diagnosis awal knee osteoarthritis. ${ }^{16}$ Hasil yang ditemukan nantinya yakni peserta penelitian yang mengalami knee osteoarthritis dan tidak mengalami knee osteoarthritis. Pemeriksaan low back pain miogenik selanjutnya dilakukan oleh peneliti utama. Pemeriksaan low back pain miogenik dilakukan dengan pengisian kuisioner Rolland Moris Low Back Pain and Disability. Validitas kuisioner ini yakni $(r<0,355)$ dan realibilitas kuisioner yakni $(r=0,877) .{ }^{17}$ Quisioner ini memilki 17 item pertanyaan tertutup dengan pilihan jawaban "ya" dan "tidak" terkait nyeri punggung bawah. Interpretasi dari kuisioner ini yaitu jika peserta penelitian memilih jawaban "ya" diatas 3 pertanyaan maka peserta penelitian mengalami low back pain. Jika interpretasi kuisioner peserta penelitian mengalami low back pain maka akan dilakukan 
palpasi dibagian punggung bawah. Palpasi dilakukan dengan mengarahkan peserta penelitian untuk duduk dan peneliti utama melakukan palpasi pada bagian lumbal (L1-L5). ${ }^{18}$ Palpasi dilakukan untuk memeriksa apakah low back pain yang dialami peserta penelitian adalah low back pain tipe miogenik.

Data yang didapat kemudian dianalisis menggunakan analisis univariat dan analisis bivariat. Analisis univariat dilakukan untuk mengetahui deskriptif data tiap variabel yakni usia, indeks massa tubuh, jenis kelamin, kejadian knee osteoarthritis dan keluhan low back pain miogenik. Analisis bivariat dilakukan dengan uji chi-square untuk menentukan hubungan antara kejadian knee osteoarthritis dan keluhan low back pain miogenik.

HASIL

Tabel 1. Karakteristik Usia dan Indeks Massa Tubuh Peserta Penelitian

\begin{tabular}{ccccc}
\hline & Mean & Median & Minimum & Maximum \\
\hline Usia & 52,5 & 52 & 40 & 70 \\
Indeks Massa Tubuh & 28,1 & 27,7 & 24,9 & 35,7 \\
\hline
\end{tabular}

Berdasarkan Tabel 1. dapat dilihat bahwa dari 52 orang peserta penelitian memiliki nilai rata-rata usia 52,5 tahun dengan usia termuda peserta penelitian yaitu 40 tahun dan usia tertua peserta penelitian yaitu 70 tahun. Indeks massa tubuh memiliki nilai rata-rata $28,1 \mathrm{~kg} / \mathrm{m}^{2}$ dengan indeks massa tubuh terendah bernilai $24,9 \mathrm{~kg} / \mathrm{m}^{2} \mathrm{dan}$ tertinggi bernilai $35,7 \mathrm{~kg} / \mathrm{m}^{2}$.

Tabel 2. Karakteristik Jenis Kelamin Peserta Penelitian

\begin{tabular}{ccc}
\hline Jenis Kelamin & Frekuensi (N) & Persentase (\%) \\
\hline Perempuan & 42 & 80,8 \\
Laki-laki & 10 & 19,2 \\
Total & 52 & 100 \\
\hline
\end{tabular}

Berdasarkan Tabel 2. dapat dilihat bahwa dari 52 orang peserta penelitian, 80,8\% (42 orang) merupakan perempuan dan 19,2\% (10 orang) dari peserta penelitian merupakan laki-laki.

Tabel 3. Distribusi Frekuensi Keluhan Low Back Pain Miogenik Peserta Penelitian

\begin{tabular}{ccc}
\hline Keluhan Low Back Pain Miogenik & Frekuensi (N) & Persentase (\%) \\
Ada & 26 & 50,0 \\
Tidak ada & 26 & 50,0 \\
Total & 52 & 100 \\
\hline
\end{tabular}

Berdasarkan Tabel 3. dapat dilihat bahwa dari 52 orang yang menjadi peserta penelitian, didapatkan hasil yang sama antara peserta penelitian yang mengeluhkan low back pain miogenik yaitu 26 orang peserta penelitian (50\%) serta 26 orang peserta penelitian (50\%) tidak mengeluhkan low back pain miogenik.

Tabel 4. Persentase Keluhan Low Back Pain Miogenik Berdasarkan Jenis Kelamin

\begin{tabular}{ccccccc}
\hline Keluhan & \multicolumn{3}{c}{ Jenis Kelamin } & \multicolumn{2}{c}{ Total } \\
\cline { 2 - 6 } Low Back Pain & Perempuan & \multicolumn{2}{c}{ Laki-laki } & \multicolumn{2}{c}{} \\
\cline { 2 - 6 } Miogenik & $\mathbf{n}$ & $\%$ & $\mathbf{n}$ & $\%$ & $\mathbf{n}$ & $\%$ \\
\hline Ya & 19 & 45,2 & 7 & 70 & 26 & 50 \\
Tidak & 23 & 54,8 & 3 & 30 & 26 & 50 \\
Jumlah & 42 & 100 & 10 & 100 & 52 & 100 \\
\hline
\end{tabular}

Dilihat dari Tabel 4. didapatkan bahwa persentase peserta penelitian berjenis kelamin perempuan yang mengeluhkan low back pain miogenik sebesar $45,2 \%$ sedangkan yang tidak mengeluhkan low back pain miogenik pada peserta penelitian berjenis kelamin perempuan yakni sebesar $54,8 \%$. Peserta penelitian berjenis kelamin laki-laki yang mengeluhkan low back pain miogenik yakni sebesar $70 \%$ dan yang tidak mengeluhkan low back pain miogenik pada peserta penelitian nerjenis kelamin laki-laki sebesar $30 \%$.

Tabel 5. Distribusi Kejadian Frekuensi Knee Osteoarthritis Peserta penelitian Penelitian

\begin{tabular}{ccc}
\hline Kejadian Knee Osteoarthritis & Frekuensi (N) & Persentase (\%) \\
\hline Ya & 25 & 48,1 \\
Tidak & 27 & 51,9 \\
Total & 52 & 100 \\
\hline
\end{tabular}

Berdasarkan Tabel 5. dapat dilihat bahwa sebanyak 25 orang $(48,1 \%)$ dari 52 orang peserta penelitian mengalami knee osteoarthritis dan 27 orang $(51,9 \%)$ tidak memiliki knee osteoarthritis.

Tabel 6. Persentase Kejadian Knee Osteoarthritis Bersadarkan Jenis Kelamin

\begin{tabular}{ccccccc}
\hline \multirow{2}{*}{ Kejadian Knee Osteoarthritis } & \multicolumn{3}{c}{ Jenis Kelamin } & \multirow{2}{*}{ Total } \\
\cline { 2 - 6 } & \multicolumn{2}{c}{ Perempuan } & \multicolumn{2}{c}{ Laki-laki } & \multicolumn{1}{c}{} \\
\cline { 2 - 6 } & $\mathrm{N}$ & $\%$ & $\mathrm{n}$ & $\%$ & $\mathrm{n}$ & $\%$ \\
\hline Ya & 21 & 50 & 4 & 40 & 25 & 48,1 \\
Tidak & 21 & 50 & 6 & 60 & 27 & 51,9 \\
Jumlah & 42 & 100 & 10 & 100 & 52 & 100 \\
\hline
\end{tabular}


Berdasarkan Tabel 6. dapat dilihat bahwa peserta penelitian berjenis kelamin perempuan yang mengalami knee osteoarthritis sebesar $50 \%$. Sedangkan peserta penelitian berjenis kelamin perempuan yang tidak mengalami knee osteoarthritis memiliki persentase yang sama dengan yang mengalami knee osteoarthritis yakni sebesar $50 \%$. Persentase peserta penelitian berjenis kelamin laki-laki yang mengalami knee osteoarthritis yaitu $40 \%$ dan persentase peserta penelitian berjenis kelamin laki-laki yang tidak mengalami knee osteoarthritis sebesar $60 \%$.

Tabel 7. Hubungan Kejadian Knee Osteoarthritis dengan Keluhan Low Back Pain Miogenik

\begin{tabular}{cccccccc}
\hline \multirow{2}{*}{ Kejadian Knee Osteoarthritis } & \multicolumn{3}{c}{ Keluhan Low Back Pain Miogenik } & \multicolumn{2}{c}{ Total } & \multirow{2}{*}{ Nilai p } \\
\cline { 2 - 7 } & $\mathrm{n}$ & $\%$ & $\mathrm{n}$ & $\%$ & $\mathrm{n}$ & $\%$ & \\
Ya & 13 & 25 & 12 & 23,1 & 25 & 48,1 & \multirow{2}{*}{0,781} \\
Tidak & 13 & 25 & 14 & 26,9 & 27 & 51,9 & \\
Jumlah & 26 & 50 & 26 & 50 & 52 & 100 & \\
\hline
\end{tabular}

Hasil uji chi-square yang tercantum pada Tabel 7. menunjukan nilai signifikansi sebesar 0,781 yang menunjukkan bahwa tidak ada hubungan yang signifikan antara kejadian knee osteoarthritis dengan keluhan low back pain miogenik pada 52 orang peserta penelitian yang merupakan masyarakat Pasar Kreneng Kota Denpasar. Tabel 7 juga menggambarkan hasil penelitian yakni presentase peserta penelitian yang mengalami knee osteoarthritis dan mengeluhkan low back pain miogenik sebesar $25 \%$. Persentase peserta penelitian yang mengalami knee osteoarthritis namun tidak mengeluhkan low back pain miogenik sebesar $23,1 \%$. Sedangkan persentase peserta penelitian yang tidak mengalami knee osteoarthritis dan mengeluhkan low back pain miogenik sebesar $25 \%$. Peserta penelitian yang tidak mengalami knee osteoarthritis dan tidak mengeluhkan low back pain miogenik sebesar $26,9 \%$.

\section{DISKUSI}

\section{Karakteristik Peserta Penelitian}

Peserta penelitian ini merupakan pedagang, pembeli, dan elemen masyarakat lainnya di Pasar Kreneng. Jumlah peserta penelitian sebanyak 52 orang yang telah memenuhi kriteria yang telah ditentukan sebelumnya. Hasil penelitian yang dijelaskan pada tabel 1 ditemukan bahwa rerata usia pada peserta penelitian yakni 52,5 tahun dengan peserta penelitian termuda berusia 40 tahun dan peserta penelitian tertua berusia 70 tahun. Hasil rerata indeks massa tubuh seperti yang dijelaskan pada tabel 1 dan ditemukan hasil rata-rata yakni $28,1 \mathrm{~kg} / \mathrm{m}^{2}$ dengan indeks massa tubuh terendah bernilai $24,9 \mathrm{~kg} / \mathrm{m}^{2}$ dan indeks massa tubuh tertinggi mencapai $35,7 \mathrm{~kg} / \mathrm{m}^{2}$. Penelitian terdahulu yang meneliti hubungan knee osteoarthritis dengan usia dan indeks massa tubuh menemukan hasil 22 dari 24 peserta penelitian berusia $>50$ tahun dan $75 \%$ dari peserta penelitian mempunyai berat badan gemuk dengan $66,7 \%$ mengalami knee osteoartritis grade $3 .{ }^{19}$ Secara biomekanis bahwa, kekuatan otot dari quadriceps merupakan salah satu faktor penting terhadap distribusi beban pada permukaan persendian. Berkurangnya kekuatan otot akan mengubah persebaran beban tersebut yang dapat menimbulkan tambahan beban pada kartilago persendian dan mengakibatkan degenerasi kartilago secara progresi. Tingginya kadar liptin pada orang yang obesitas mempunyai hubungan terkait sitokin proinflamatori yang berperan dalam kerusakan degeneratif yang dialami peserta penelitian. ${ }^{20}$ Hasil penelitian juga menunjukkan mayoritas peserta penelitian merupakan perempuan yakni sebanyak 42 orang $(80,8 \%)$ dan laki-laki hanya berjumlah 10 orang $(19,2 \%)$.

Frekuensi keluhan low back pain miogenik yang didapat dari penelitian ini dilihat dari tabel 3 didapatkan sebanyak 26 orang peserta penelitian (50\%) mengalami low back pain miogenik dan 26 orang lainnya (50\%) tidak mengalami low back pain miogenik. Hingga saat ini penelitian terkait low back pain miogenik masih kurang dan agak sulit ditemui. Jika dilihat kembali pada tabel 4 persentase peserta penelitian berjenis kelamin perempuan yang mengeluhan low back pain miogenik adalah $45,2 \%$ dan yang tidak mengeluhkan low back pain miogenik sebesar $54,8 \%$. Pada peserta penelitian berjenis kelamin laki-laki, persentase peserta penelitian yang mengeluhkan low back pain miogenik lebih banyak jika dibandingkan dengan peserta penelitian berjenis kelamin laki-laki yang tidak mengeluhkan low back pain miogenik yakni sebesar $70 \%$ sementara yang tidak mengeluhkan low back pain miogenik memiliki persentase sebesar $30 \%$. Keluhan low back pain miogenik pada laki-laki memiliki persentase yang lebih besar bila dibandingkan dengan peserta penelitian berjenis kelamin perempuan. Salah satu penyebab persentase keluhan low back pain pada laki-laki lebih banyak jika dibandingkan dengan perempuan dikarenakan aktivitas fisik yang dilakukan oleh laki-laki lebih banyak dengan manual handling. Kegiatan manual handling merupakan kegiatan mengangkat, menarik, serta memegang alat pada saat bekerja. Aktivitas manual lifting ini dapat menyebabkan cedera dan nyeri pada bagian punggung bawah. ${ }^{21}$

Pada tabel 5 terlihat bahwa jumlah peserta penelitian yang mengalami knee osteoarthritis yakni sebanyak 25 orang $(48,1 \%)$ dan peserta penelitian yang tidak mengalami knee osteoarthritis berjumlah 27 orang $(51,9 \%)$. Sedangkan gambaran persentase peserta penelitian dengan knee osteoarthritis seperti pada tabel 6 didapatkan bahwa pada peserta penelitian berjenis kelamin perempuan yang mengalami dan tidak mengalami knee osteoarthritis memiliki persentase yang sama yakni $50 \%$. Pada peserta penelitian berjenis kelamin laki-laki persentase peserta penelitian yang mengalami knee osteoarthritis lebih sedikit jika dibandingan dengan persentase peserta penelitian berjenis laki-laki yang tidak mengalami knee osteoarthritis yakni sebesar $40 \%$ sedangkan yang tidak mengalami knee osteoarthritis sebesar $60 \%$.

Berdasarkan jenis kelamin, knee osteoarthritis memang lebih sering terjadi pada perempuan. Hal ini disebabkan oleh faktor hormonal yaitu kekurangan hormon estrogen ketika akan menopause, pengaruh estrogen pada knee osteoarthritis adalah pada bagian osteoblas dan sel endotel. Jika estrogen turun, maka akan terjadi penurunan TGF- $\beta$ yang dihasilkan osteoblas dan nitric oxide (NO) yang dihasilkan sel endotel sehingga mengakibatkan diferensiasi dan peningkatan maturasi osteoklas. Hormon ini juga berpengaruh pada bone marrow stroma cell dan sel mononuklear 
yang dapat menghasilkan HIL-1, TNF- $\alpha$, IL-6 dan M-CSF sehingga dapat terjadi osteoarthritis karena mediator inflamasi ini.22

Kejadian knee osteoarthrtitis pada peserta penelitian berjenis kelamin laki-laki dapat disebabkan oleh beberapa hal diantaranya aktivitas fisik dan obesitas. Laki-laki lebih sering melakukan aktivitas fisik berat seperti kegiatan berdiri lama dan mengangkat barang. ${ }^{14}$ Aktivitas fisik berat dapat menjadi salah satu faktor risiko terjadi knee osteoarthritis. Laki-laki juga lebih berisiko untuk mengalami obesitas. Penelitiannya juga menemukan bahwa laki-laki yang mengalami obesitas akan memperberat aktivitas fisik karena adanya tambahan beban pada sendi lutut. ${ }^{23}$ Tabel 6 menggambarkan bahwa persentase peserta penelitian berjenis kelamin laki-laki yang mengalami knee osteoarthritis sebesar $40 \%$ dan peserta penelitian berjenis kelamin laki-laki yang tidak mengalami knee osteoarthritis sebesar $60 \%$. Hasil ini dapat disebabkan oleh beberapa hal yakni tidak adanya kontrol aktivitas fisik yang dilakukan pada peserta penelitian dan peserta penelitian yang digunakan pada penelitian ini adalah masyarakat Pasar Kreneng Kota Denpasar dimana yang menjadi peserta pada penelitian ini memungkinkan belum mengalami keluhan nyeri pada lutut.

\section{Hubungan Kejadian Knee Osteoarthritis dengan Keluhan Low Back Pain Miogenik}

Berdasarkan pada tabel 7 terlihat bahwa jumlah peserta penelitian yang mengalami knee osteoarthritis dan mengeluhkan low back pain miogenik yakni sebanyak 13 orang atau sebesar $25 \%$, sedangkan jumlah peserta penelitian knee osteoarthritis yang tidak mengalami low back pain miogenik berjumlah 12 orang atau sebesar 23,1\%. Pada tabel 7 juga menggambarkan peserta penelitian yang tidak mengalami knee osteoarthritis namun mengeluhkan low back pain miogenik sebanyak 13 orang atau sebesar $25 \%$ sedangkan peserta penelitian yang tidak mengalami knee osteoarthritis dan tidak mengeluhkan low back pain miogenik sejumlah 14 orang peserta penelitian (26,9\%).

Dari hal tersebut diketahui bahwa seperempat atau 25\% dari total peserta penelitian masyarakat Pasar Kreneng Kota Denpasar mengalami knee osteoarthritis dan mengeluhkan low back pain miogenik. Hasil analisis Chi-Square test selanjutnya ditemukan nilai $p$ sebesar $0,781(p>0,05)$ yang dapat diartikan sebagai tidak adanya hubungan signifikan antara kejadian knee osteoarthritis dengan keluhan low back pain miogenik pada masyarakat Pasar Kreneng Kota Denpasar.

Nilai $p$ yang tidak signifikan dari uji Chi-Square test mungkin dikarenakan oleh beberapa hal, seperti alat ukur knee osteoarthritis yang kurang akurat dan peserta penelitian yang menyangkal pertanyaan kuisioner. Penelitian terdahulu terkait komorbiditas low back pain dan nyeri muskuloskeletal lain pada individu dengan knee osteoarthritis symptomatic melakukan inklusi peserta penelitian dengan salah satu kriterianya yakni peserta penelitian didiagnosis knee osteoarthritis melalui pemeriksaan radiografi dan setidaknya memiliki derajat 2 Kellgren and Lawrence. ${ }^{15}$ Sementara pada penelitian ini, diagnosis knee osteoarthritis dibantu oleh fisioterapis dan tidak dilakukan pemeriksaan radiografi untuk menentukan derajat knee osteoarthritis pada peserta penelitian. Tauchi et al., pada tahun 2015 menemukan jika perubahan derajat inklinasi spinal lumbal terjadi pada penderita knee oateoarthritis dengan derajat 2 skala Kellgren and Lawrence dan pada derajat knee osteoarthritis awal (derajat 0 - 1 skala Kellgren and Lawrence) belum ditemukan adanya perubahan pada derajat inklinasi spinal lumbal. ${ }^{24}$

Nilai $p$ yang tidak signifikan juga dapat dipengaruhi penyimpangan informasi yang dikumpulkan oleh peneliti yaitu clever hans effect yang merupakan perubahan respon subjek agar sesuai dengan apa yang (dianggap oleh subjek) menyenangkan peneliti. ${ }^{25}$ Pada penelitian ini, beberapa peserta penelitian menjawab poin-poin pada kuisioner Rolland Morris Low Back Pain and Disability dengan cepat dan melakukan penyangkalan agar mempercepat wawancara yang dilakukan.

Nilai $p$ yang tidak signifikan ini juga mungkin terjadi karena peserta penelitian yang digunakan tidak representatif sebab adanya perbedaan aktivitas fisik pada peserta penelitian dan pemilihan peserta penelitian yang kurang tepat digunakan seperti jenis kelamin dan usia. Subjek representatif merupakan subjek yang menggambarkan karakteristik yang hampir sama dengan yang dimiliki populasi. ${ }^{26}$ Aktivitas fisik dicurigai menjadi salah satu faktor pada penelitian ini sehingga menghasilkan peserta penelitian yang tidak representatif. Peserta penelitian yang digunakan pada penelitian ini ialah pedagang, pembeli, serta elemen masyarakat lainnya di Pasar Kreneng seperti tukang parkir dan buruh pasar. Aktivitas fisik yang dilakukan tiap peserta penelitian tentu intensitasnya tidak akan sama. Jika dilihat dari pekerjaan yang dilakukan, buruh pasar pada Pasar Kreneng Kota Denpasar cenderung melakukan aktivitas berat seperti kegiatan angkut muat barang berat. Sedangkan untuk padagang, pembeli, dan tukang parkir lebih banyak melakukan aktivitas fisik dengan intensitas ringan sampai sedang seperti melakukan kegiatan berbelanja dan mengarahkan kendaraan untuk diparkirkan. Saat melakukan penelitian, hal ini luput dari pertanyaan peneliti. Tingkat aktivitas dapat meningkatkan risiko seseorang terkena knee osteoarthritis terutama tingkat aktivitas fisik yang berat. Nilai $p$ yang tidak signifikan dicurigai terjadi karena faktor aktivitas fisik yang dilakukan peserta penelitian saat pengambilan data dilakukan. ${ }^{27}$

Faktor selanjutnya yang dicurigai mempengaruhi peserta penelitian sehingga tidak representatif adalah pemilihan peserta penelitian berdasarkan jenis kelamin. Pada penelitian ini, jumlah peserta penelitian yang digunakan adalah 52 orang dengan penjabaran yaitu 42 orang $(80,8 \%)$ peserta penelitian merupakan perempuan dan 10 orang $(19,2 \%)$ peserta penelitian merupakan laki-laki. Jumlah peserta penelitian yang tidak sama ini menyebabkan data menjadi tidak homogen atau tidak menggambar tiap jenis kelamin memiliki peluang yang sama untuk menjadi peserta penelitian penelitian. Jika dilihat kembali, perbedaan jenis kelamin pada peserta penelitian ini juga dapat menyebabkan perbedaan pada kejadiaan knee osteoarthritis mengingat kejadian knee osteoarthritis salah satunya dapat disebabkan oleh hormon yaitu estrogen. Hormon estrogen ini selanjutnya dapat menyebabkan kejadian knee osteoarthrtitis dapat lebih berisiko terjadi pada perempuan. Hal ini sejalan dengan penelitian terdahulu yang mengatakan bahwa laki-laki mempunyai angka kejadian knee osteoarthritis lebih rendah dari pada perempuan. ${ }^{28}$

Nilai $p$ yang tidak signifikan ini juga dicurigai terjadi karena pemilihan peserta penelitian berdasarkan usia. Peserta pada penelitian ini adalah orang yang berusia $\geq 40$ tahun sampai 75 tahun. Kejadian knee osteoarthritis di Bali 
paling banyak terjadi pada usia $55-74$ tahun. ${ }^{13}$ Pemilihan rentang usia yang digunakan pada penelitian ini juga dicurigai sebagai salah satu faktor yang menyebabkan nilai $p$ tidak signifikan.

Faktor lain yang dapat menyebabkan nilai $p$ yang tidak signifikan pada penelitian ini adalah perspetif nyeri pada peserta penelitian. Tiap individu memiliki perspektif nyeri yang berbeda. Perbedaan perspektif nyeri ini dapat dipengaruhi beberapa hal diantaranya genetik, jenis kelamin, keadaan psikologis dan interaksi sosial pada individu. ${ }^{29}$ Pada penelitian ini terdapat prosedur yakni menanyakan peserta penelitian terkait nyeri pada bagian punggung bawah, adanya perbedaan perspektif nyeri ini memungkinkan terjadinya bias saat peserta penelitian menjawab pertanyaan terkait nyeri yang diberikan oleh peneliti.

Berdasarkan nilai $p$ yang tidak signifikan pada penelitian ini, peneliti merekomendasikan agar yang menjadi peserta penelitian sudah terdiagnosis secara radiografi dan memiliki knee osteoarthritis grade $\geq 2$ skala Kellgren and Lawrence. Peserta penelitian juga direkomendasikan hanya berjenis kelamin perempuan saja mengingat kejadian knee osteoarthritis lebih banyak terjadi pada perempuan.

\section{SIMPULAN}

Berdasarkan hasil penelitian dapat disimpulkan bahwa tidak ada hubungan yang signifikan antara kejadian knee osteoarthritis dengan keluhan low back pain miogenik pada masyarakat Pasar Kreneng Kota Denpasar. Nilai $p$ yang tidak signifikan ini dipengaruhi oleh faktor alat ukur, peserta penelitian yang tidak representatif, motivasi, persepsi nyeri, dan aktivitas fisik peserta penelitian.

\section{DAFTAR PUSTAKA}

1. Dinkes Bali. Profil Kesehatan Provinsi Bali. 2014. Profil Kesehatan Provinsi Bali Tahun 2013 , p. 21.

2. Soeroso dkk J., Isbagio H., Kalim H., Broto R., Pramudiyo R. Osteoartritis, Buku Ajar Ilmu Penyakit Dalam. 2009.Edisi pertama. Internal Publishing. Jakarta. h.2539-2549.

3. Neogi, T. Epidemiology of Osteoarthritis. 2012.. The Clinics Rheumatic , 1-3

4. Allen, K. DEpidemiology of Osteoarthritis: State of The Evidence. 2015. Thurston Arthritis Research Center , 1-16.

5. Boyan BD., Tosi L., Coutts R., Enoka R., Hart DA., Nicolella DP., Kohrt W. Sex Differences in Osteoarthritis of the Knee. 2012. Journal of the American Academy of Orthopaedic Surgeons, 20(10).

6. Lee, K. M.. Risk Factors For Osteoarthritis And Contributing Factors To Current Arthritic Pain In South Korean Older Adults. 2016. Yonsei Med Journal, 1-2.

7. Coggon, D. Knee Osteoarthritis And Obesity. 2001. International Journal of Obesity , 1-6.

8. Sharma, L., Song, J., Dunlop, D., Felson, D., Lewis, C. E., Segal, N. Nevitt, M. Varus and valgus alignment and incident and progressive knee osteoarthritis. Annals of the Rheumatic Diseases. 2010. 69(11), 1940-1945.

9. Brandt, K. D. Etiopathogenesis of Osteoarthritis. 2008. Rheumatic Disease Clinic Of North America , 531-535.

10. Cudejko, T. Proprioception Mediates The Association Between Systemic Inflammation And Muscle Weakness In Patients With Knee Osteoarthritis:Results From The Amsterdam Osteoarthritis Cohort. 2018. Amsterdam: Jurnal of Rehabiltation Medicine

11. Rice, D. A. Mechanisms of Quadriceps Muscle Weakness In Knee Joint Osteoarthritis: The Effects of Prolonged Vibration on Torque and Muscle Activation in Osteoarthritic and Healthy Control. Subjects2011. Arthritis Research \& Therapy , 1-3.

12. Aulia, R., Perbedaan Efek Antara Core Stability Exercise Dengan William's Flexion Exercise Terhadap Disabilitas Dan Kekuatan Otot Pada Low Back Pain Miogenik. 2016. UEU jurnal, pp. 3-5.

13. Adhiputra, I. K. Osteoarthritis. 2017 Kota Denpasar: SIMDOS UNUD

14. Liandari, F., Indriani. Faktor Resiko Kejadian Penyakit Osteoartritis pada Pekerja Usia 35-65 Tahun di Pasar Beringharjo Yogyakarta. 2019

15. Suri, P., Morgenroth, D. C., Kwoh, C. K., Bean, J. F., Kalichman, L., \& Hunter, D. J. Low back pain and other musculoskeletal pain comorbidities in individuals with symptomatic osteoarthritis of the knee: Data from the osteoarthritis initiative. 2010. Arthritis Care \& Research, 62(12), 1715-1723

16. Abari I.S. 2016 ACR Revised Criteria for Early Diagnosis of Knee Osteoarthritis. 2016. Autoimmune Dis Ther Approaches.

17. Widiasih G. Hubungan Posisi Belajar dan Lama Duduk dengan Kejadian Nyeri Punggung Bawah Mahasiswa PSPD FKIK UIN Jakarta. 2015. Skripsi. Program Studi Pendidikan Dokter UIN Syarif Hidayatullah Jakarta. Jakarta

18. Allegri, M. Mechanisms of Low back pain: A Guide For Diagnosis Andtherapy. 2016. F1000Research , 1-7.

19. Mutiwara, E., Narjiman, Afriwadi. Hubungan Indeks Massa Tubuh dengan Derajat Kerusakan Sendi pada Pasien Osteoartritis Lutut di RSUP Dr. M. Djamil Padang. 2015. Jurnal Kesehatan Andalas, 5(2), 376-380.

20. Widhiyanto, L., Desnantyo, A.T., Djuari, L., Kharismansha, M. Correlation Between Knee Osteoarthritis (Oa) Grade And Body Mass Index (Bmi) In Outpatients Of Orthopaedic And Traumatology Department Rsud Dr. Soetomo. 2017. Journal Orthopaedi and Traumatology Surabaya, 6(2), 71-79

21. Nurzannah, Sinaga M., Salmah U. Hubungan Faktor Resiko Dengan Terjadinya Nyeri Punggung Bawah (low back pain) pada Tenaga Kerja Bongkar Muat (TKBM) dipelabuhan Belawan Medan Tahun 2015. 2015

22. Roman-Blas, J. A., Castañeda, S., Largo, R., \& Herrero-Beaumont, G. Osteoarthritis associated with estrogen deficiency. 2009. Arthritis Research \& Therapy, 11(5), 241. doi:10.1186/ar2791

23. Soutakbar H., Lamb S.E., Silman. The different influence of high levels of physical activity on the incidence of knee OA in overweigght and obese men and women - a gender spesific analysis. 2019. Osteoarthritis and Cartilage Journal

24. Tauchi R., Imagama S., Muramoto A., Tsuboi M., Ishiguro N., Hasegawa Y. Influence of Spinal Imbalance on Knee Osteoarthritis in Community-living Eldery Adults. 2015. Nagoya J. Med. 
25. Putra, I.W.G.A.E., Sutarga, I.M. Tutorial Kesalahan Sitematik (Bias) dan Cara Penanggulangannya.2020. Dilihat 18 Juni 2020, (diakses di situs; https://simdos.unud.ac.id/uploads/file pendidikan 1 dir/a0a7a25ece94487a2b953ea4bc9fc332.pdf )

26. Arens, Alvin., , Randal J. Elder, Mark S. Beasley. Auditing and. Assurance Services: An Integrated Approach, 1.3th Edition, Pearson. 2012. Prentice Hall

27. Sinoel K.R., Majdawati A. Hubungan Aktivitas Fisik Dengan Gambaran Radiologi pada Kejadian Osteoartritis Lutut. 2017. Repository UMY.

28. Heidari, B. Knee Osteoarthritis Prevalence, Risk Factors, Pathogenesis And Features: Part I. Caspian. 2011. Journal of International Med, 206-210.

29. Coghill, R.C. Individual Difference in the Subjective Experience of Pain: New Insight into Mechanisms and Models. 2010. National Institute of Health 